\title{
ANALISIS PENGARUH KUALITAS PRODUK, KUALITAS PELAYANAN DAN PROMOSI TERHADAP KEPUASAN KONSUMEN \\ ELSA HIJAB SEMARANG
}

\author{
Mitha Alifia Roselina ${ }^{1}$ \\ Asih Niati ${ }^{2}$ \\ mithasooyoung@gmail.com ${ }^{1}$ \\ asih_niati@usm.ac.id ${ }^{2}$
}

Fakultas Ekonomi Universitas Semarang

Diterima: Mei 2019, Disetujui: Juni 2019, Dipublikasikan: Juli 2019

\begin{abstract}
This study aims to analyze the effect of product quality, service quality and promotion on customer satisfaction in Elsa Hijab Semarang.

This research was conducted with quantitative methods. The number of samples in this study amounted to 96 respondents who were consumers of Elsa Hijab Semarang. The technique used in this study uses Purporsive Sampling techniques. The data analysis used was descriptive and multiple linear regression analysis.

The results of this study indicate that product quality, service quality and promotion have a positive and significant effect on customer satisfaction.

Keywords : Product quality, service quality, promotion and satisfaction consumer.

ABSTRAK

Penelitian ini bertujuan untuk menganalisis pengaruh kualitas produk, kualitas layanan dan promosi terhadap kepuasan pelanggan di Elsa Hijab Semarang.

Penelitian ini dilakukan dengan metode kuantitatif. Jumlah sampel dalam penelitian ini berjumlah 96 responden yang merupakan konsumen Elsa Hijab Semarang. Teknik yang digunakan dalam penelitian ini menggunakan teknik Purporsive Sampling. Analisis data yang digunakan adalah analisis deskriptif dan analisis regresi linier berganda.

Hasil penelitian ini menunjukkan bahwa kualitas produk, kualitas layanan dan promosi memiliki pengaruh positif dan signifikan terhadap kepuasan pelanggan.
\end{abstract}

Kata kunci: Kualitas produk, kualitas layanan, promosi dan kepuasan konsumen. 


\section{PENDAHULUAN}

Dalam persaingan yang makin ketat ini, banyak perusahaan yang berlombalomba untuk merebut hati dan minat para konsumen, dengan memenuhi segala permintaan konsumen, mengikuti trend yang sedang booming, bahkan meningkatkan kualitas pelayan dari perusahaan itu sendiri. Demikian halnya dengan persaingan pasar busana muslim, yang dari tahun ketahunnya selalu meciptakan berbagai model yang patut untuk diikuti. Adanya dengan persaingan tersebut perusahaan dituntut harus mulai memikirkan apa saja yang menjadi kebutuhan konsumen pada saat ini maupun dimasa yang akan datang nanti.

Masyarakat Indonesia mayoritas memeluk agama islam, tentunya akan meningkatkan jumlah pemakai busana muslim khususnya jilbab, dengan begitu busana muslim menjadi peluang bisnis untuk para pengusaha yang menggeluti bisnis tersebut. Dengan mengikuti perkembangan gaya hidup sekarang ini, model busana muslim yang dulu hanya dikenal dengan busana yang sederhana sekarang beralih menjadi busana dengan tampilan yang lebih modis, elegan dan trendy.

Kepuasan pelanggan merupakan sesuatu hal yang harus diutamakan oleh perusahaan demi keberlangsungan usahanya. Untuk memenuhi kepuasan pelanggan, Elsa Hijab Semarang selalu memperhatikan faktor-faktor penting dalam bauran pemasaran seperti kualitas produk, kualitas pelayanan dan promosi agar mampu bersaing dengan pesaingnya.

Dapat dilihat keadaaan sebenarnya pelaksanaan kualitas produk, kualitas pelayanan, dan promosi belum mampu mendorong konsumen merasa puas terhadap produk Elsa Hijab. Berdasarkan dari dakta yang terjadi pada Elsa hijab, maka dapat dilihat selama terdapat data penurunan penjualan selama tiga periode tahun sebagai berikut : 
Tabel 1.1

Data Penjualan Per Item Produk

Tahun 2016-2018

\begin{tabular}{|c|c|c|c|}
\hline Bulan & 2016 & 2017 & 2018 \\
\hline Januari & 182 & 164 & 174 \\
\hline Pebruari & 170 & 168 & 153 \\
\hline Maret & 172 & 153 & 162 \\
\hline April & 179 & 174 & 169 \\
\hline Mei & 188 & 273 & 214 \\
\hline Juni & 284 & 248 & 227 \\
\hline Juli & 261 & 159 & 148 \\
\hline Agustus & 168 & 167 & 134 \\
\hline September & 159 & 158 & 147 \\
\hline Oktober & 167 & 175 & 153 \\
\hline November & 173 & 167 & 149 \\
\hline Desember & 185 & 173 & 135 \\
\hline Jumlah & 2.288 & 2.179 & 1.992 \\
\hline
\end{tabular}

Sumber : Elsa Hijab Semarang

Berdasarkan tabel 1.1 dapat diketahui bahwa jumlah penjualan Elsa Hijab Semarang dari tahun ke tahun mengalami penurunan. Pada tahun 2016 jumlah penjualan sebanyak 2.288, kemudian pada tahun 2017 terjadi penurunan sejumlah 2.179 item produk, kemudian pada tahun berikutnya terjadi penurunan kembali 1.992 item produk. Hal ini mengindikasikan bahwa terdapat penurunan kepuasan konsumen yang mengakibatkan menurunnya jumlah penjualan item produk.

Rumusan Masalah

Perumusan masalah penelitian adalah bagaimana cara meningkatkan kepuasan konsumen di Elsa Hijab Semarang, sehingga pertanyaan dalam penelitian ini adalah sebagai berikut :

1. Bagaimana pengaruh kualitas produk terhadap kepuasan konsumen pada Elsa HIjab Semarang? 
2. Bagaimana pengaruh kualitas pelayanan terhadap kepuasan konsumen pada Elsa HIjab Semarang?

3. Bagaimana pengaruh promosi terhadap kepuasan konsumen pada Elsa HIjab Semarang?

\section{Tujuan Penelitian}

Adapun tujuan penelitian ini sebagai berikut:

1. Untuk menganalisis pengaruh kualitas produk terhadap kepuasan konsumen pada Elsa Hijab Semarang.

2. Untuk menganalisis pengaruh kualitas pelayanan produk terhadap kepuasan konsumen pada Elsa Hijab Semarang.

3. Untuk menganalisis pengaruh promosi terhadap kepuasan konsumen pada Elsa Hijab Semarang.

\section{LANDASAN TEORI}

\section{Kepuasan Konsumen}

Menurut Christian, dkk (2016) Kepuasan konsumen adalah keadaan konsumen baik yang merasa puas maupun belum puas setelah tercapai keinginan dan harapan terhadap menu, harga, fasilitas dan pelayanan yang disediakan. Konsumen akan merasa puas apabila keinginan dan harapan yang diterima terpenuhi, sebaliknya konsumen akan merasa belum puas apabila keinginan dan harapan yang diterima belum terpenuhi.Menurut Kotler dan Keller (2009:138) menyatakan bahwa kepuasan konsumen adalah perasaan senang atau kecewa seseorang yang timbul karena membandingkan kinerja yang dipersepsikan produk (hasil) terhadap ekspetasi mereka.

\section{Kualitas Produk}

Menurut Kotler dan Amstrong (2010:27) Kualitas produk adalah kemampuan suatu produk untuk melaksanakan fungsinya, meliputi kehandalan, daya tahan, ketepatan, kemudahan operasi, dan perbaikan produk, serta atribut bernilai lainnya.Menurut (Wijaya 2011:11) dalam (Johanes,2014)Kualitas adalah sesuatu yang diputuskan oleh pelanggan, artinya kualitas didasarkan pada 
pengalaman aktual pelanggan atau konsumen terhadap produk atau jasa yang diukur berdasarkan persyaratan-persyaratan tersebut. Dari pengertian diatas dapat disimpulkan bahwa kualitas produk adalah kepuasan suatu produk yang diputuskan oleh pelanggan yang didasarkan pada pengalaman aktual terhadap ptoduk atau jasa yang diukur berdasarkan ketentuan yang ada.

\section{Kualitas Pelayanan}

Menurut Kotler (2002:83) dalam (Kasino, 2017), definisi pelayanan adalah setiap tindakan atau kegiatan yang dapat ditawarkan oleh suatu pihan kepada pihak lain, yang pada dasarnya tidak berwujud dan tidak mengakibatkan kepemilikan apapun. Produksinya dapat dikaitkan atau tidak dikaitkan pada satu produk fisik. Menurut (Wijaya;2011) dalam (Teguh Iman, 2018), kualitas pelayanan adalah ukuran seberapa bagus tingkat layanan yang diberikan mampu sesuai dengan ekspatasi pelanggan. Berdasarkan pengertian diatas dapat disimpulkan bahwa kualitas pelayanan merupakan suatu tindakan atau kegiatan untuk mengukur seberapa baik tingkat pelayanan yang diberikan mampu sesuai dengan harapan pelanggan.

\section{Promosi}

Promosi menurut Suryadi (2011:8) dalam (Jessica J, 2014) adalah serangkaian kegiatan untuk mengkomunikasikan, memberi pengetahuan dan meyakinkan orang tentang suatu produk agar ia mengakui kehebatan produk tersebut, juga mengikat pikiran dan perasaannya dalam suatu wujud loyalitas terhadap produk. Menurut (Manap;2016) dalam (Inda, 2019) Promosi sejenis komunikasi yang memberikan penjelasan yang meyakinkan calon konsumen tentang barang dan jasa. Semakin sering promosi produk tersebut dilakukan semakin mendorong minat konsumen agar semakin tertarik dan terpengaruh untuk melakukan kegiatan pembelian. promosi adalah kegiatan penting bagi perusahaan untuk mengenalkan dan memberitahukan manfaat dari sebuah produk baru kepada konsumen, untuk membujuk konsumen agar membeli produk sehingga melakukan transaksi antara pembeli dan penjual. Dari pengertian diatas dapat disimpulkan bahwa promosi adalah kegiatan untuk mengkomunikasikan tentang suatu produk 
kepada orang lain untuk dapat mempengaruhi mengajak, membujuk dan memberi informasi dari suatu produk yang ditawarkan.

\section{Kerangka pemikiran Teoritis}

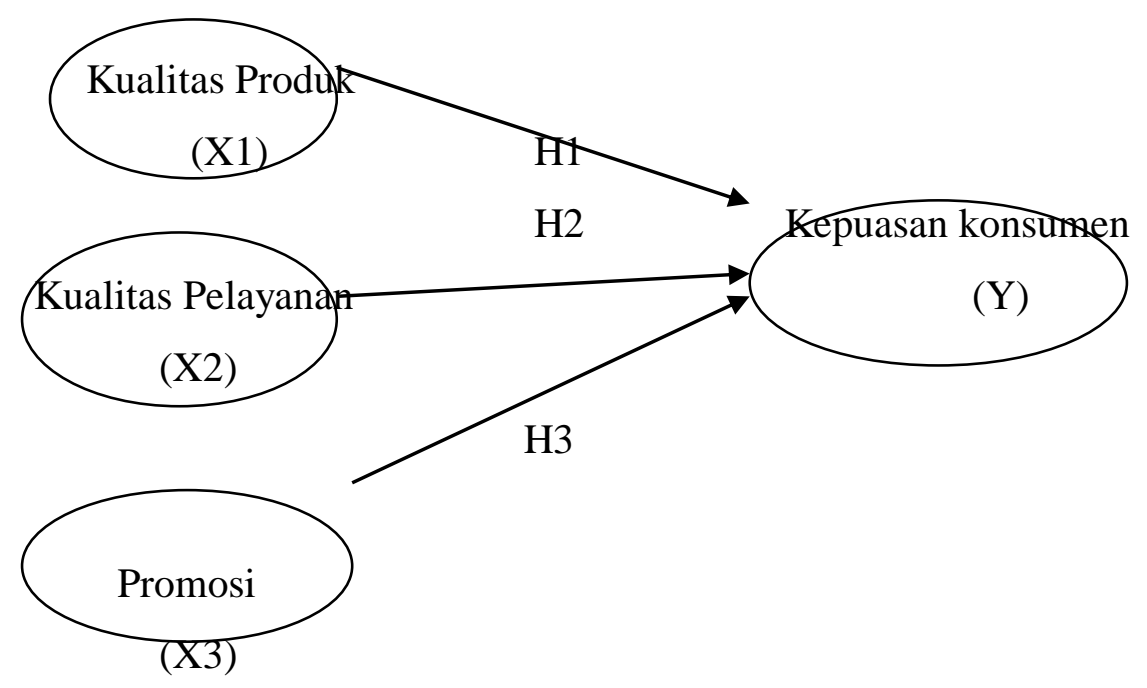

\section{METODE PENELITIAN}

\section{Populasi dan Sampel}

Populasi menurut (Sugiyono, 2016) adalah wilayah generalisasi yang terdiri atas obyek atau subyek yang mempunyai kualitas dan karakteristik tertentu yang ditetapkan guna untuk dipelajari dan kemudian ditarik kesimpulannya. Populasi yang dimaksud dalam penelitian ini adalah konsumen Elsa Hijab.

Sampel merupakan bagian dari jumlah dan karakteristik yang dimiliki oleh populasi tersebut (Sugiyono, 2016). Dalam hal ini populasinya tidak diketahui dengan pasti, maka menurut (Sugiyono, 2016) dasar penentuan sampel ditentukan dengan rumus :

$$
n=\frac{z^{2}}{4(m o e)^{2}}
$$


Keterangan :

$\mathrm{n} \quad=$ Jumlah sampel

$\mathrm{z}^{2}=$ Tingkat kepercayaan $95 \%$ berarti $\mathrm{Z}=1,96$

Moe = Margin Of Error, yaitu kesalahan maksimal yang dapat ditoleransikan, ditentukan sebesar 10\%. Sehingga jumlah sampel yang dihasilkan adalah:

$$
n=\frac{1,96^{2}}{4(0,1)^{2}}
$$

$n=96,04($ Dibulatkan menjadi 96)

Berdasarkan perhitungan di atas sampel yang diambil dalam penelitian yang diperoleh sebesar 96 responden. Teknik pengambilan sampel yang digunakan dalam penelitian ini adalah Purposive Sampling. Teknik sampling berdasarkan kriteria. Adapun kriteria orang yang diambil sebagai sampel adalah :

1. Konsumen yang pernah membeli dan mengunjungi butik Elsa Hijab Semarang.

2. Konsumen yang berusia di atas 17 tahun.

\section{Analisis Regresi Linier}

Analisis yang digunakan untuk mengukur kekuatan hubungan antara dua variabel atau lebih, juga menunjukkan arah hubungan antara variabel dependen dan variabel independen (Ghozali, 2016). Analisis regresi linier adalah pengembangan analisis regresi sederhana terhadap aplikasi yang terdiri dari tiga lebih variabel independen atau bebas yaitu kualitas Produk(X1), Kualitas Pelayanan (X2), dan Promosi (X3) untuk menduga nilai dari variabel dependen atau terikat yaitu Kepuasan Konsumen (Y). Bentuk persamaan regresi penelitian ini adalah sebagai berikut :

$\mathrm{Y}=\mathrm{a}+\mathrm{b}_{1} \mathrm{x}_{1}+\mathrm{b}_{2} \mathrm{x}_{2}+\mathrm{b}_{3} \mathrm{x}_{3}+\mathrm{e}$

Dimana :

$\mathrm{Y}=$ Kepuasan Konsumen

a $\quad$ Konstanta 


$$
\begin{array}{ll}
\mathrm{b}_{1} \mathrm{~b}_{2} \mathrm{~b}_{3} & =\text { Koefisien Regresi } \\
\mathrm{X}_{1} & =\text { Kualitas Produk } \\
\mathrm{X}_{2} & =\text { Kualitas Pelayanan } \\
\mathrm{X}_{3} & =\text { Promosi } \\
\mathrm{e} & =\text { Standard eror }
\end{array}
$$

\section{Uji Hepotesis Parsial (Uji T)}

Untuk membuktikan hipotesis dalam penelitian ini apakah variabel bebas berpengaruh terhadap variabel terikat, maka digunakan pengujian yaitu uji-t (Ghozali, 2016). Untuk menguji apakah masing-masing variabel bebas (kualitas produk, kualitas pelayanan dan promosi) berpengaruh secara signifikan terhadap variabel terikat (kepuasan konsumen) secara parsial.

\section{Koefisien Determinasi (R2)}

Koefisien determinasi $\left(\mathrm{R}^{2}\right)$ pada intinya mengukur seberapa jauh kemampuan model dalam menerangkan variasi variabel dependen. Nilai koefisian determinasi adalah antara nol dan satu. Nilai $\mathrm{R}^{2}$ yang kecil berarti kemampuan variabel-variabel independen dalam menjelaskan variasi variabel dependen terbatas. Nilai yang mendekati satu berarti variabel-variabel independen memberikan hampir semua informasi yang di butuhkan untuk memprediksi variasi-variasi dependen (Ghozali, 2016).

\section{Pembahasan}

\section{Pengaruh Kualitas Produk Terhadap Kepuasan Konsumen}

Berdasarkan hasil penelitian dapat diketahui thitung $(3,740)>\mathrm{t}$ tabel $(1,985)$ dan Sig. $(0,000)<0,05$. Artinya variabel kualitas produk berpengaruh signifikan terhadap kepuasan konsumen Elsa Hijab Semarang. Hal ini berarti bahwa semakin baik kualitas produk maka semakin tinggi kepuasan konsumen.Penelitian ini sesuai dengan teori yang dikemukakan oleh (Armstrong; 2008) yaitu kualitas produk adalah karakteristik yang bergantung pada kemampuannya untuk memuaskan kebutuhan konsumen. Oleh karena itu kualitas produk menjadi perhatian utama bagi perusahaan untuk memuaskan konsumen. Produk yang 
ditawarkan setiap badan usaha akan berbeda dan pasti mempunyai karakteristik yang membedakan produk itu dengan produk pesaing walaupun jenis produknya sama sehingga produk itu memiliki keunikan, keistimewaan, keunggulan dalam meraih pasar yang ditargetkan.

Hasil penelitian ini sejalan oleh penelitian yang dilakukan Nasution dan Kurniawati (2018) yang menyatakan bahwa kualitas produk berpengaruh positif terhadap kepusan konsumen.

\section{Pengaruh Kualitas Pelayanan Terhadap Kepuasan Konsumen}

Berdasarkan hasil penelitian dapat diketahui t hitung $(2,580)>t$ tabel $(1,985)$ dan Sig. $(0,011)<0,05$. Artinya variabel kualitas pelayanan berpengaruh signifikan terhadap kepuasan konsumen Elsa Hijab Semarang. Hal ini berarti bahwa semakin baik kualitas pelayanan maka semakin tinggi kepuasan konsumen.Penelitian ini sesuai dengan teori yang dikemukakan oleh (Tjiptono, 2014) bahwa kualitas pelayanan merupakan tingkat keunggulan yang diharapkan dan pengendalian atas keunggulan tersebut untuk memenuhi keinginan konsumen. Sehingga dapat dikatakan bahwa apabila pelayanan yang diberikan mampu untuk memenuhi kebutuhan atau melampaui harapan konsumen, maka konsumen tersebut merasa puas.

Hasil penelitian ini sejalan oleh penelitian lain yang dilakukan Rusmawati dan Marlindawaty (2018)yang menyatakan bahwa kaulitas pelayanan berpengaruh positif terhadap kepusasn konsumen.

\section{Pengaruh Promosi Terhadap Kepuasan Konsumen}

Berdasarkan hasil penelitian dapat diketahui t hitung $(2,106)>\mathrm{t}$ tabel $(1,985)$ dan Sig. $(0,038)<0,05$. Artinya variabel promosi berpengaruh signifikan terhadap kepuasan konsumen Elsa Hijab Semarang. Hal ini berarti bahwa semakin baik promosi yang dilakukan maka semakin tinggi kepuasan konsumen.Penelitian ini sesuai dengan teori yang dikemukakan oleh (Kotler ; 2005) bahwa Promosi adalah proses, komunikasi suatu perusahaan dengan pihakpihak yang berkepentingan sekarang dan yang akan datang serta masyarakat. Agar perusahaan berhasil terhadap produk atau jasa yang ditawarkan kepada konsumen, 
harus mengkomunikasikan sejumlah informasi terhadap perusahaan, produk, struktur harga, dan sistem distribusi kepada sejumlah pemirsa yang meliputi konsumen, perantara perdagangan, dan media.

Hasil penelitian ini sejalan oleh penelitian yang dilakukan oleh Anggriana(2017) yang menyatakan bahwa promosi berpengaruh positif terhadap kepuasan konsumen.

Kesimpulan

1. Kualitas Produk berpengaruh positif dan signifikan terhadap kepuasan konsumen Elsa Hijab Semarang.

2. Kualitas Pelayanan berpengaruh positif dan signifikan terhadap kepuasan konsumen Elsa Hijab Semarang.

3. Promosi berpengaruh positif dan signifikan terhadapkepuasan konsumen Elsa Hijab Semarang.

\section{Keterbatasan Penelitian}

Berdasarkan hasil penelitian dengan variabel bebas yang digunakan masih terbatas yaitu kualitas produk, kualitas pelayanan, dan promosi terhadap kepuasan konsumen sehingga perlu adanya penambahan variabel dengan harapan kepuasan konsumen dapat terpenuhi. Nilai koefisien determinasi yang diperoleh 0,332 atau 33,2\% yang mengindikasikan bahwa kepuasan konsumen belum cukup untuk dijelaskan dari variabel kualitas produk, kualitas pelayanan, dan promosi. Sedangkan sisanya 66,8\% dijelaskan oleh faktor lain yang tidak diteliti atau diluar penelitian. Maka diharapkan kepada penelitian mendatang perlu menambah variabel lain seperi harga, lokasi, citra merek dan lain sebagainya.

\section{Saran}

Berdasarkan deskriptif hasil penelitian, kualitas produk, kualitas pelayanan, dan promosi terhadap kepuasan konsumen terdapat hasil yang menunjukkan tidak setuju dari masing-masing pernyataan yang diajukan. Dengan demikian saran dari hasil penelitian ini dapat dikembangkan berdasarkan hasil tersebut. Saran yang dapat diberikan dalam penelitian ini adalah: 
1. Berdasarkan deskripsi tanggapan responden atas kualitas produk terdapat tanggapan responden tentang kualitas kain yang kurang baik. Hal ini terjadi saat konsumen berkunjung sehingga dapat melihatnya secara langsung dan merasakan kualitas kain dari produk Elsa Hijab Semarang. Terdapat beberapa produk kerudung/hijab yang bertekstur kain kurang halus dan panas, sehingga kurang nyamaan ketika digunakan saat siang hari. Maka usaha yang bisa dilakukan pihak manajemen Elsa Hijab Semarang adalah mengganti atau memperbarui kualitas kain yang digunakan pada produk gamis dan hijab, sehingga konsumen lebih nyaman menggunakan produk tersebut.

2. Berdasarkan deskripsi tanggapan responden atas kualitas pelayanan terdapat tanggapan responden tentang karyawan kurang memberikan perhatian kepada konsumen saat memilih produk yang sesuai dengan keingian konsumen. Hal ini terlihat pada karyawan yang bertugas kurang memberikan perhatian atau memberikan saran yang terbaik kepada konsumen, terlebih saat Butik mulai ramai di jam dan hari-hari tertentu. Karyawan tergesa-gesa sehingga konsumen tidak mendapatkan produk yang diinginkan. Maka hal yang perlu dilakukan Elsa Hijab Semarang adalah karyawan lebih responsif dalam melayani pelanggan atau dengan menambah karyawan atau membagi tugas masing-masing dengan tujuan konsumen lebih merasa diutamakan saat membeli produk Elsa Hijab Semarang, maka dengan saran tersebut pelanggan dapat terlayani dengan cepat.

3. Berdasarkan deskripsi tanggapan responden mengenai promosi yaitu, kemampuan karyawan memberikan informasi dan penawaran produk kurang detail. Hal ini terjadi dikarenakan kurang maksimalnya karyawan dalam pengetahuan produk tersebut sehingga promosi tidak tersampaikan secara jelas kepada konsumen. Maka usaha yang bisa dilakukan pihak manajemen Elsa Hijab Semarang adalah memberikan pengetahuian lebih jelas baik dari bahan kain yang digunakan, model, dan harga dari produk tersebut.

4. Berdasarkan deskripsi tanggapan responden mengenai kepuasan konsumen yaitu, terdapat tanggapan yang memiliki nailai rata-rata yang paling rendah yaitu, konsumen kurang menikmati produk yang dijual. Hal ini terjadi dikarenakan kurang memaksimalkan kualitas bahan kain gamis yang 
digunakan sehingga konsumen merasa kecewa telah membelinya. Maka usaha yang bisa dilakukan pihak manajemen Elsa Hijab Semarang adalah mengganti atau memperbaiki kualitas kain yang digunakan sehingga konsumen lebih merasa nyaman dan puas atas produk yang telah dibeli.

\section{DAFTAR PUSTAKA}

Anggriana Rina et.al, 2017. "Pengaruh Harga, Promosi, Kualitas Layanan Terhadap Kepuasan Pelanggan Jasa Ojek Online "Om-Jek" Jember". JSMBI ( Jurnal Sains Manajemen Dan Bisnis Indonesia) Vol. 7 No.2 (2019) AvitaResty, 2013. "Strategi Promosi, Kualitas Produk, Kualitas Layanan Terhadap Kepuasan Pelanggan Pada Restoran Mcdonald's Manado" Jurnal EMBAVol.1 No.4Hal. 1465-1473 (2019)

Ghozali, Imam, 2013, Aplikasi Analisis Multivariate dengan Program SPSS. Edisi Ketujuh. Semarang: Badan Penerbit Universitas Diponegoro. , 2016, Aplikasi Analisis Multivariate dengan Program IBM

23. Edisi 8. Cetakan ke VIII. Semarang: Badan Penerbit Universitas Diponegoro.

Hari Christian Nugroho et.al, 2016. "Analisis Pengaruh Harga, Kualitas Produk. Dan Kualitas Pelayanan Terhadap Kepuasan Konsumen Pada Rumah Makan Sfa Steak \& Resto Di Klodran Karanganyar" Jurnal Ekonomi dan Kewirausahaan Vol. 16 No. 3: 364 - 371 (2019)

Iman Teguh dan Tri Kurniawati, 2018. "Pengaruh kualitas produk dan kualiatas pelayanan terhadap kepuasan konsumen produk nissan grand livina" ecoGen Vol 4, Vol 5 (2019)

J. Jessica et.al, 2014 "Pengaruh Kualitas Produk, Harga Dan Promosi Terhadap Kepuasan Pelanggan Kartu Prabayar Telkomsel” Jurnal EMBA, Vol.2 No.3 (2019)

J. Johanes et.al, 2014. "Pengaruh Kualitas Produk, Harga, Dan Kualitas Pelayanan Terhadap Kepuasan Pengguna Cafe Dan Resto Cabana Manado" Jurnal EMBA Vol.2 No.3Hal. 1803-1813 (2019)

Kasino, 2018. "Pengaruh Kualitas Produk, Kualitas Pelayanan, Dan Penetapan Harga Terhadap Kepuasan Pelanggan Pt. Mitra Tour \& Travel Sidoarjo" Jurnal Ekonomi \& Bisnis, Vol 3 (2019)

Kotler, Philip. 2009. Manajemen Pemasaran Jilid 1. Erlangga : Jakarta.

Kotler, Philip. 2009. Manajemen Pemasaran Jilid 2. Erlangga : Jakarta.

Ngalimin Inda G.Q et.al, 2019. "Strategi Relationship Marketing Dan Promosi Pengaruhnya Terhadap Kepuasan Konsumen Di Matahari Departement Store Mega Mall Manado" Jurnal EMBAVol.7 No.1 (2019)

Pandesia, Alvaris Edward et.al, 2017. "Pengaruh Kualitas Produk Dan Kualitas Layanan Terhadap Kepuasan Konsumen Pada Perumahan Griya Paniki Indah Manado" Jurnal EMBA Vol.5 No.2 (2019)

Ratna Safitri, Sri Utami dkk, 2017. "Analisis Pengaruh Store Atmosphere, Harga, Kualitas Pelayanan, Dan Keragaman Produk Terhadap Kepuasan Konsumen Pada Cafe \& Resto”. Jurnal Ekonomi dan Kewirausahaan, Vol 17 (2019) 
Rizan Mohamad dan Fajar Andika, 2011. "Pengaruh Kualitas Produk Dan Kualitas Pelayanan Terhadap Kepuasan Pelanggan (Survei Pelanggan Suzuki, Dealer Fatmawati, Jakarta Selatan)". Jurnal Riset Manajemen Sains Indonesia (JRMSI) Vol. 2,1 (2019)

Rusmawati dan Marlindawaty, 2018. "Analisis Kualitas Pelayanan, Harga Dan Promosi Terhadap Kepuasan Pelanggan Laundry Bjr Batakan Balikpapan" Jurnal EKSEKUTIF Vol 15 (2019). 
Majalah Ilmiah Solusi

Vol. 17, No. 3 Juli 2019

ISSN : 1412-5331

Halaman ini sengaja dikosongkan 